\title{
Geochemistry of circum-craton eclogites and other mafic xenoliths from the Kaapvaal craton, southern Africa, and their comparison to on-craton equivalents
}

\author{
Christel Tinguely ${ }^{\mathbf{1}, 2}$, Anton le Roex ${ }^{\mathbf{1}}$, Michel Grégoire ${ }^{\mathbf{2}}$ \\ ${ }^{1}$ Department of Geological Sciences, University of Cape Town, South Africa \\ ${ }^{2}$ UMR5562, DTP, OMP, 15 avenue Edouard Belin, Toulouse, France
}

\begin{abstract}
Major and trace element and isotope geochemistry of constituent minerals from eclogites and related mafic xenoliths (garnet clinopyroxenites, garnet websterites) from five circum-craton localities (Lovedale, Roodekraal, Jachtfontein, Markt and Goedehoop) situated along the southwestern margin of the Kaapvaal craton, southern Africa, are reported. A comparison is made to equivalent lithologies from the on-craton localities of Roberts Victor (Hatton, 1978), Jagersfontein and Jwaneng.
\end{abstract}

\section{Major element chemistry}

Clinopyroxenes in circum-craton eclogites sensu largo are omphacites, with high jadeite contents (14.3-50.4 mole $\%$ ), corresponding to high $\mathrm{Na}_{2} \mathrm{O}$ contents (2.607.15 wt.\%). In contrast, clinopyroxenes in circumcraton garnet clinopyroxenites and garnet websterites are diopsides, with lower $\mathrm{Na}_{2} \mathrm{O}$ contents $(0.25-2.85$ wt.\%). $\mathrm{Al}_{2} \mathrm{O}_{3}$ contents are higher in omphacites (5.3614.13 wt. $\%)$ than in diopsides (0.78-5.35 wt.\%), while $\mathrm{FeO}^{*}$ contents are similar (2.00-8.62 wt.\% for omphacites and 1.89-6.99 wt.\% for diopsides). Diopsides have higher $\mathrm{CaO}$ (19.3-24.6 wt.\%) and $\mathrm{MgO}$ (13.2-17.7 wt.\%) contents than omphacites (11.6-19.5 wt.\% and 6.55-13.1 wt.\%, respectively). Mg\#'s vary between 0.661 and 0.913 for omphacites and between 0.781 and 0.942 for diopsides. When compared to oncraton clinopyroxenes, the circum-craton clinopyroxenes in both eclogites and clinopyroxenites/websterites show similar composition in all major elements except $\mathrm{MgO}$, for which circumcraton clinopyroxenes have lower values at similar sodium content. Omphacites from circum-craton kyanite eclogites show lower $\mathrm{Al}_{2} \mathrm{O}_{3}$ contents than omphacites from on-craton kyanite eclogites, at a given $\mathrm{Na}_{2} \mathrm{O}$ content. Garnets in equilibrium with diopsides have low and restricted range in $\mathrm{CaO}$ contents (4.135.79 wt.\%), compared to garnets in equilibrium with omphacites (4.21-12.94 wt.\%). Garnets in the two lithologies have similar $\mathrm{FeO}^{*}$ contents (11.3-25.8 wt.\% and 12.4-23.6 wt.\% when in equilibrium with omphacite or diopside, respectively), with garnets in kyanite eclogites having a more restricted range in FeO* (12.7-16.5 wt.\%). All garnets have low amounts of $\mathrm{Na}_{2} \mathrm{O}(<0.21 \mathrm{wt} . \%)$, and display a large variation in $\mathrm{MgO}$ contents (7.2-16.2 wt.\% and 10.0-16.2 wt.\% when in equilibrium with omphacite and diopside, respectively), which leads to a large, and overlapping, variation in $\mathrm{Mg} \#$ values for both lithologies (35.5-69.7 and 43.9-69.8, respectively). All garnets have low $\mathrm{Cr}_{2} \mathrm{O}_{3}$ contents $(<0.28$ wt.\%), except those that equilibrated with significant amounts of orthopyroxene, which have higher $\mathrm{Cr}$ (0.21-2.14 wt.\% $\left.\mathrm{Cr}_{2} \mathrm{O}_{3}\right)$. When compared to garnets from on-craton xenoliths, garnets from off-craton settings show similar contents in $\mathrm{Ca}$ but slightly higher contents in $\mathrm{Fe}$ and/or lower contents in $\mathrm{Mg}$.

\section{Trace element mineral composition}

Most off-craton clinopyroxenes exhibit convex-upward chondrite-normalized REE patterns, with LREE being higher in omphacites $\left(\mathrm{La}_{\mathrm{N}}=1.40-81.4\right)$ than in diopsides $\left(\mathrm{La}_{\mathrm{N}}=1.65-33.7\right)$. MREE enrichment is variable $\left(\mathrm{Sm}_{\mathrm{N}}\right.$ : 5.12-86.1 for omphacites and $\mathrm{Sm}_{\mathrm{N}}$ : 8.88-94.9 for diopsides), whereas HREE contents are low in clinopyroxene from all lithologies $\left(\mathrm{Yb}_{\mathrm{N}}=0.14\right.$ 1.57 for omphacites and $\mathrm{Yb}_{\mathrm{N}}=0.14-0.90$ for diopsides). When compared to on-craton clinopyroxenes $\left(\mathrm{La}_{\mathrm{N}}=0.76-47.9\right.$ and $\left.\mathrm{Sm}_{\mathrm{N}}=1.26-32.9\right)$, off-craton clinopyroxenes appear enriched in LREE and especially in MREE (figure 1).

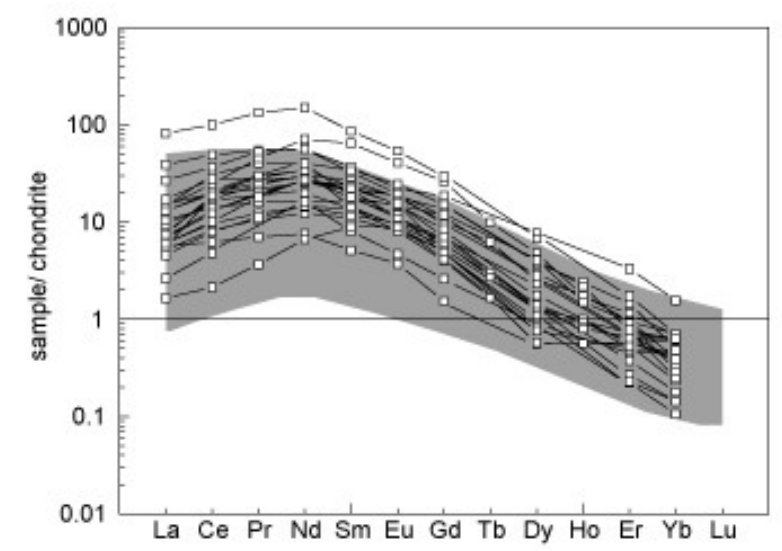

Fig.1: Chondrite-normalized REE patterns for cpx from circum-craton xenoliths. The grey field represents the REE patterns for on-craton cpx from Jagersfontein, Jwaneng and Roberts Victor.

Chondrite-normalized REE patterns for garnets in equilibrium with diopsides exhibit a rather steep positive slope from LREE to MREE $\left[(\mathrm{Ce} / \mathrm{Nd})_{\mathrm{N}}=0.04-\right.$ 0.52] that flattens down from MREE to HREE [with 
$\left.(\mathrm{Gd} / \mathrm{Yb})_{\mathrm{N}}: 0.26-1.61\right]$, whereas garnets in equilibrium with omphacites exhibit a strong positive slope from LREE to MREE $\left[(\mathrm{Ce} / \mathrm{Nd})_{\mathrm{N}}=0.04-0.17\right]$, a "hump" towards $\mathrm{Sm}$ and $\mathrm{Eu}$ (Sm abundances of 6 to 48 times chondrites) and a slight negative slope from $\mathrm{Gd}$ to $\mathrm{Yb}$ $\left[(\mathrm{Gd} / \mathrm{Yb})_{\mathrm{N}}=0.84-4.9\right]$. Significant positive $\mathrm{Eu}$ anomalies in garnets are observed in eclogites from Roodekraal and Jachtfontein $\left(\mathrm{Eu} / \mathrm{Eu}^{*}=1.24-1.84\right)$. Both groups of garnets are strongly depleted in LREE $\left(\mathrm{Ce}_{\mathrm{N}}\right.$ : 0.032-1.6), and enrichment in HREE is variable $\left(\mathrm{Yb}_{\mathrm{N}}\right.$ : 4.8-32.2 and $\mathrm{Yb}_{\mathrm{N}}$ : 8.9-39.8 for garnets in equilibrium with omphacites and diopsides, respectively, with garnets from one sample from Roodekraal having a $\mathrm{Yb}_{\mathrm{N}}$ value of 91.6). When compared to on-craton garnets $\left(\mathrm{Sm}_{\mathrm{N}}\right.$ : $0.98-10.5, \mathrm{Yb}_{\mathrm{N}}$ : 2.20-22.3), off-craton garnets appear enriched in MREE and HREE (figure 2).

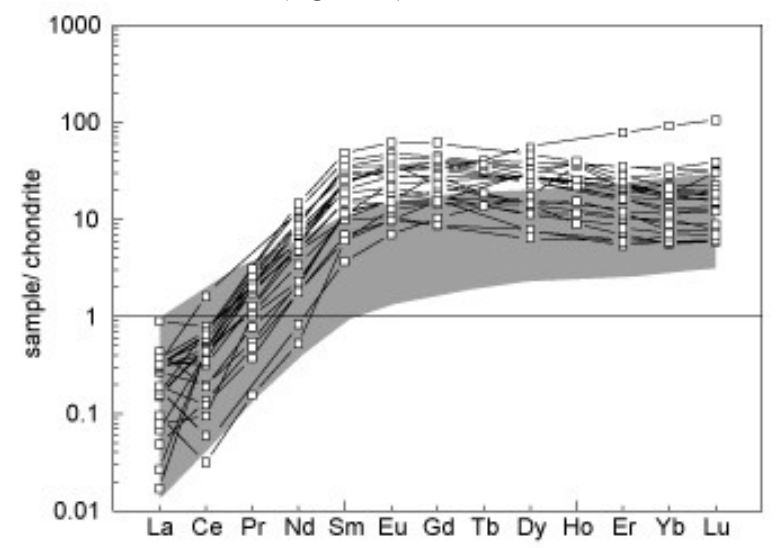

Fig. 2: Chondrite-normalised REE patterns for garnets from circum-craton xenoliths. The grey field represents the REE patterns for on-craton garnets from Jagersfontein, Jwaneng and Roberts Victor.

\section{Stable and radiogenic isotopes}

Oxygen isotope analyses on garnets from circumcraton localities yield $\delta^{18} \mathrm{O}$ values ranging between 5.15 and $6.78 \%$ o for eclogites and between 5.24 and $7.03 \%$ for garnet clinopyroxenites. In comparison, garnets from the on-craton Roberts Victor, Jwaneng and Jagersfontein localities give $\delta^{18} \mathrm{O}$ values ranging from 4.68 to $6.70 \%$, although published data from Roberts Victor give a range of 2.2-8.0\%o. Present-day $\mathrm{Sr}$ isotope compositions determined on circum-craton clinopyroxenes give overlapping, to slightly higher, values for eclogites $\left({ }^{87} \mathrm{Sr} /{ }^{86} \mathrm{Sr}: 0.70352-0.70708\right)$ than for garnet clinopyroxenites $\quad\left({ }^{87} \mathrm{Sr} /{ }^{86} \mathrm{Sr}\right.$ : $0.70254-$ $0.70620)$. Clinopyroxenes in garnet websterites yield lower ${ }^{87} \mathrm{Sr} /{ }^{86} \mathrm{Sr}$ values of $0.70267-0.70345$. In comparison, on-craton eclogitic clinopyroxenes exhibit a wide range of ${ }^{87} \mathrm{Sr} /{ }^{86} \mathrm{Sr}$ values $(0.70277-0.70889)$, garnet clinopyroxenites have a narrower overlapping range (0.70353-0.70518), and the single garnet websterite gives a value of 0.70734 . Low $\mathrm{Rb}$ contents in the clinopyroxene result in minimal age correction even over $2 \mathrm{Ga}$. Ranges in ${ }^{143} \mathrm{Nd} /{ }^{144} \mathrm{Nd}$ ratios for clinopyroxenes are low and similar between the circum-craton eclogites (0.51191-0.51268) and the circum-craton garnet clinopyroxenites (0.511810.51264). Clinopyroxenes from the circum-craton websterites overlap to slightly higher values of $0.51207-0.51271 .{ }^{143} \mathrm{Nd} /{ }^{144} \mathrm{Nd}$ ratios for on-craton eclogitic clinopyroxenes $(0.51209-0.51259)$ are within the range of values defined by the circum-craton equivalents, and clinopyroxene from on-craton garnet clinopyroxenites show a limited range of ${ }^{143} \mathrm{Nd} /{ }^{144} \mathrm{Nd}$ values (0.51272-0.51276) similar to their circum-craton counterparts. Among circum-craton xenoliths, eclogitic clinopyroxenes exhibit higher present-day ${ }^{206} \mathrm{~Pb} /{ }^{204} \mathrm{~Pb}$ ratios (17.26-19.45) and ${ }^{208} \mathrm{~Pb} /{ }^{204} \mathrm{~Pb}$ ratios (37.11-41.93) than clinopyroxenes from clinopyroxenites $\left({ }^{206} \mathrm{~Pb} /{ }^{204} \mathrm{~Pb}\right.$ : 16.85-17.78 and ${ }^{208} \mathrm{~Pb} /{ }^{204} \mathrm{~Pb}$ : 36.77-37.45). Clinopyroxenes from on-craton garnet clinopyroxenites show higher ${ }^{206} \mathrm{~Pb} /{ }^{204} \mathrm{~Pb}$ values (19.01-20.69) and ${ }^{208} \mathrm{~Pb} /{ }^{204} \mathrm{~Pb}$ values (38.94-38.97) than their circumcraton counterparts. In contrast, both ${ }^{206} \mathrm{~Pb} /{ }^{204} \mathrm{~Pb}$ and ${ }^{208} \mathrm{~Pb} /{ }^{204} \mathrm{~Pb}$ ratios are higher for circum-craton eclogitic clinopyroxenes than for their on-craton counterparts $\left({ }^{206} \mathrm{~Pb} /{ }^{204} \mathrm{~Pb}\right.$ : $15.00-17.50$ and ${ }^{208} \mathrm{~Pb} /{ }^{204} \mathrm{~Pb}: 35.24-37.38$, respectively).

\section{Geothermobarometry}

Equilibrium temperatures were estimated using thermometers of Ellis and Green (1979) and Krogh (1988). For the orthopyroxene-bearing samples, equilibrium temperatures and pressures were estimated using the geobarometer of Brey and Köhler (1990). An assumed pressure of $30 \mathrm{~kb}$ was used in the calculations. Temperatures obtained for the garnet websterites are the lowest with all thermometers $\left(\mathrm{T}_{\mathrm{EG}}: 742-781^{\circ} \mathrm{C}, \mathrm{T}_{\mathrm{K}}\right.$ : $669-697^{\circ} \mathrm{C}$, and $\mathrm{T}_{\mathrm{BK}}$ : $739-820^{\circ} \mathrm{C}$ ), whereas garnet clinopyroxenites appear to have equilibrated at slightly higher temperatures $\left(\mathrm{T}_{\mathrm{EG}}: 715-830^{\circ} \mathrm{C}\right.$ and $\mathrm{T}_{\mathrm{K}}$ : 635$748^{\circ} \mathrm{C}$ ). Ranges in temperature obtained for the eclogite xenoliths are wide, with $\mathrm{T}_{\mathrm{EG}}=707-1056^{\circ} \mathrm{C}$ (mean $913^{\circ} \mathrm{C}$ ) and $\mathrm{T}_{\mathrm{K}}=633-1064^{\circ} \mathrm{C}\left(\right.$ mean $\left.887^{\circ} \mathrm{C}\right)$, and results for kyanite eclogites $\left(\mathrm{T}_{\mathrm{EG}}\right.$ : $940-1010^{\circ} \mathrm{C}$ and $\mathrm{T}_{\mathrm{K}}$ : $930-1001^{\circ} \mathrm{C}$ ) indicate equilibration at the high end of this temperature range. Equilibration pressures obtained for the orthopyroxene-bearing samples range from $16 \mathrm{~kb}$ to $33 \mathrm{~kb}$. Temperatures of equilibration estimated on eclogites from Roberts Victor by Harte and Kirkley (1997) at an assumed pressure of $50 \mathrm{~kb}$ give $\mathrm{T}_{\mathrm{EG}}$ values ranging from 947 to $1285^{\circ} \mathrm{C}$, and temperatures obtained for eclogites from Jagersfontein with the same geothermometer are more restricted in range $\left(1020-1072{ }^{\circ} \mathrm{C}\right.$; at $\left.50 \mathrm{~kb}\right)$. Temperatures obtained for the two eclogites from Jwaneng give an average value of $960^{\circ} \mathrm{C}$.

\section{Discussion and conclusions}

Mafic mantle xenoliths brought to the surface along the southwestern margin of the Kaapvaal craton can be subdivided into two lithological groups, namely omphacite-bearing (eclogites sensu largo) and diopside-bearing rocks (garnet clinopyroxenites, garnet websterites). When compared to their cratonic counterparts, clinopyroxenes and garnets in circumcratonic eclogites exhibit lower $\mathrm{MgO}$ contents and higher MREE abundances, with garnets sowing a flatter HREE pattern. Temperatures of equilibration for 
the different circum-craton xenoliths (at $\mathrm{P}=30 \mathrm{~kb}$ ) increase from the garnet websterites $\left(\mathrm{T}_{\mathrm{EG}}=742-781^{\circ} \mathrm{C}\right)$ through the garnet clinopyroxenites $\left(\mathrm{T}_{\mathrm{EG}}=715-830^{\circ} \mathrm{C}\right)$ to eclogites $\left(\mathrm{T}_{\mathrm{EG}}=707-1056^{\circ} \mathrm{C}\right.$, mean value of $\left.913^{\circ} \mathrm{C}\right)$. Pressures of equilibration obtained for the orthopyroxene-bearing samples vary between 16 and $33 \mathrm{~kb}$ (corresponding to depths of $\sim 50-100 \mathrm{~km}$ ). Based on geophysical studies indicating the occurrence of 45 to $50 \mathrm{~km}$ of crust underneath this circum-cratonic region, we argue that the circum-craton suite as a whole originate from the upper mantle rather than from the lower Proterozoic crust. The temperatures and pressures of equilibration obtained for these xenoliths correspond to shallower depths than those at which the on-craton xenoliths equilibrated, believed to be within the diamond stability field.

Raised oxygen isotope values in garnets from circum-craton eclogites and clinopyroxenites, are interpreted as resulting from the low-temperature alteration of the protolith at crustal depths. A low pressure protolith is supported by the common occurrence of positive $\mathrm{Eu}$ anomalies in garnets, clinopyroxene and in many recalculated bulk-rock chondrite-normalized REE patterns. Low but variable ${ }^{87} \mathrm{Sr} /{ }^{86} \mathrm{Sr}$ ratios, MORB to HIMU-like $\mathrm{Pb}$ isotope ratios and depleted, although in some cases complex, chondrite-normalised bulk rock REE patterns, are consistent with derivation from a geochemically depleted protolith, interpreted to be oceanic crust. In contrast, the very low ${ }^{143} \mathrm{Nd} /{ }^{144} \mathrm{Nd}$ ratios of the clinopyroxenes require an episode of enrichment (metasomatism) undergone by the xenoliths or their protoliths, the former supported by the presence of secondary phlogopite observed in many samples. Noteworthy is the presence of minerals with mixed geochemical signature which is indicative of the complex interactions between the mantle and the melts/fluids percolating through it in subcontinental environment.

\section{References}

Brey, G.P. and Köhler, T., 1990. Geothermobarometry in four-phase lherzolites II. New thermobarometers, and practical assessment of existing thermobarometers. Journal of Petrology 31, Part 6, 1,353-1,378.

Ellis, D.J. and Green, D.H., 1979. An experimental study of the effect of $\mathrm{Ca}$ upon garnet-clinopyroxene $\mathrm{Fe}-\mathrm{Mg}$ exchange equilibria. Contributions to Mineralogy and Petrology 71, 13-22.

Harte, B. and Kirkley, M.B., 1997. Partitioning of trace elements between clinopyroxene and garnet: data from mantle eclogites. Chemical Geology 136, 1-24.

Hatton, C.J., 1978. The geochemistry and origin of xenoliths from the Roberts Victor mine. Unpublished $\mathrm{PhD}$ thesis, University of Cape Town, $180 \mathrm{pp}$.

Krogh, E.J., 1988. The garnet-clinopyroxene Fe-Mg geothermometer - a reinterpretation of existing experimental data. Contributions to Mineralogy and Petrology 99, 44-48.

Mattey, D.P., Lowry, D., Macpherson, C.G., Chazot, G. Oxygen isotope composition of mantle minerals by laser fluorination analysis: homogeneity in peridotites, heterogeneity in eclogites. Mineralogical Magazine 58A (1994) 573-574. 